\title{
AKTSAR
}

ISSN 2622-5255 (online)

Volume 1 Nomor 2, Desember 2018, Halaman 215-232

ISSN 2622-2345 (cetak)

\section{Pengaruh Return on Asset, Net Profit Margin, dan Earning Per Share Terhadap Harga Saham Perusahaan Rokok Go Public}

\author{
Irsad Andriyanto \\ Institut Agama Islam Negeri Kudus \\ irsad.smg@gmail.com \\ Silvia Khoirunnisa \\ Institut Agama Islam Negeri Kudus \\ nisasilvia@gmail.com
}

\begin{abstract}
This study aimed to investigate empirically influence the company characteristics proxied by return on assets, net profit margin, and earning per share on the stock price of cigarette companies listed in IDX. The Investment was the decision taken to allocate assets in order to get benefit in the future. This study was explanatory research using a quantitative approach to analyze the sample of cigarette companies listed in IDX from 2015 to 2017. The data are taken from IDX then analyzed by multiple linear regression analysis supported by SPSS. The results showed that the return on assets and earnings per share did not have a significant influence on the stock price. Moreover, the net profit margin was the most influential variable on stock prices. Net profit margin showed a high level of efficiency, so it became an important factor that the company should consider because of its significant impact on the stock prices.
\end{abstract}

Keywords: ROA; NPM; EPS; Stock price. 


\begin{abstract}
ABSTRAK
Penelitian ini bertujuan untuk mengetahui secara empiris pengaruh karakteristik perusahaan yang diproksi dengan return on assets, net profit margin, dan earning per share terhadap harga saham perusahaan rokok yang terdaftar di BEI. Investasi adalah keputusan yang diambil untuk mengalokasikan aset untuk mendapatkan manfaat di masa depan. Penelitian ini menggunakan pendekatan kuantitatif untuk menganalisis sampel perusahaan rokok yang terdaftar di BEI dari tahun 2015 hingga 2017. Data yang diambil dari BEI kemudian dianalisis dengan analisis regresi linier berganda yang didukung oleh SPSS. Hasil penelitian menunjukkan bahwa return on asset dan earning per share tidak berpengaruh signifikan terhadap harga saham. Selain itu, net profit margin adalah variabel yang paling berpengaruh terhadap harga saham. Net profit margin menunjukkan tingkat efisiensi yang tinggi, sehingga menjadi faktor penting yang harus dipertimbangkan oleh perusahaan karena pengaruhnya yang signifikan terhadap harga saham.
\end{abstract}

Kata Kunci: ROA; NPM; EPS; Harga saham

\title{
PENDAHULUAN
}

Pasar modal dipandang sebagai salah satu sarana yang efektif untuk mempercepat pembangunan suatu negara. Hal ini dimungkinkan karena pasar modal merupakan wahana yang dapat menggalang pengarahan dana jangka panjang dari masyarakat untuk disalurkan ke sektor-serktor yang produktif. Dalam menjalankan fungsi ekonominya, pasar modal menyediakan fasilitas untuk memindahkan dana dari lender yaitu pihak yang mempunyai kelebihan dana, kepada borrower, yaitu pihak yang memerlukan dana (Astuti, Retnowati, dan Rosyid, 2015).

Dengan menginvestasikan kelebihan dana yang mereka miliki, lenders atau investor mengharapkan akan memperoleh imbalan dari penyerahan dana tersebut. Dari sisi borrowers, tersedianya dana dari pihak luar memungkinkan mereka melakukan investasi tanpa harus menunggu tersedianya dana dari hasil operasi perusahaan. Dalam proses ini diharapkan akan terjadi peningkatan produksi, sehingga akhirnya secara keseluruhan akan terjadi peningkatan kemakmuran. Fungsi ini sebenarnya juga dilakukan oleh intermediasi keuangan lainnya, seperti lembaga perbankan, hanya bedanya dalam pasar modal diperdagangkan dana jangka panjang. Fungsi keuangan dilakukan dengan menyediakan dana yang diperlukan oleh borrowers, dan pada lenders atau investor menyediakan dana tanpa harus terlibat langsung dalam kepemilikan aktiva riil yang diperlukan untuk investasi tersebut (Nazir, 2016).

Nilai perusahaan tercermin dalam nilai pasar sahamnya, sehingga semakin tinggi harga saham maka semakin tinggi pula nilai perusahaannya terlebih bagi perusahaan yang sudah go public. Saham merupakan salah satu surat berharga yang dikeluarkan oleh perusahaan yang naik turunnya harga saham dipengaruhi oleh banyak faktor. Salah satu faktor yang mempengaruhi harga saham adalah kemampuan perusahaan membayar dividen. Apabila dividen yang dibayar tinggi, 
harga saham cenderung tinggi sehingga nilai perusahaan juga ikut tinggi. Sebaliknya bila dividen yang dibayarkan kecil maka harga saham perusahaan tersebut rendah sehingga nilai perusahaan rendah. Kemampuan membayar dividen erat hubungannya dengan kemampuan perusahaan memperoleh laba. Tinggi rendahnya harga saham ini juga merupakan refleksi dari keputusan investasi, keputusan pendanaan dan pengelolaan aset tersebut (Wibowo, 2013).

Sektor industri rokok merupakan salah satu sektor strategis domestik yang memiliki daya saing tinggi dan memberikan kontribusi signifikan terhadap perekonomian nasional. Peranan tembakau dan produk-produk turunannya dapat dilihat dari beberapa sisi, yaitu (1) penerimaan negara (dari bea dan cukai); (2) penyerapan tenaga kerja; (3) komoditas bagi petani; (4) beasiswa pendidikan; (5) sponsor sektor olahraga. Berdasarkan data bea dan cukai Kementerian Keuangan, 90\% penerimaan cukai berasal dari Industri Hasil Tembakau (IHT). Dalam APBN 2017 pendapatan negara dari cukai rokok mencapai Rp. 149,9 triliun, naik 6\% dari APBN 2016. Di sisi lain, kemampuan finansial industri rokok menjadikan sumber pendanaan berbagai kegiatan seperti halnya sektor olahraga (Kiyat, 2012).

\section{TINJAUAN LITERATUR}

\section{Pasar Modal}

Pasar modal (capital market) merupakan pasar untuk berbagai instrumen keuangan jangka panjang yang bisa diperjualbelikan, baik dalam bentuk utang ataupun modal sendiri (Kennedy, Zheng, Tang, Paganin, \& Jesson, 2010). Dengan demikian, tujuan pasar modal adalah mempercepat proses ikut sertanya masyarakat dalam kepemilikan saham menuju pemerataan pendapatan masyarakat serta meningkatkan partisipasi masyarakat dalam pengerahan dana dan penggunaannya secara produktif untuk pembiayaan pembangunan nasional. Sedangkan yang dimaksud dengan efek adalah surat berharga yang berupa surat pengakuan utang, surat berharga komersial, saham, obligasi, tanda bukti utang, bukti right (right issue), waran (warrant).

Produk-produk yang terdapat dalam pasar modal, antara lain saham, obligasi, dan reksadana.

\section{Saham}

Saham merupakan penyertaan dalam modal dasar suatu perseroan terbatas, sebagai tanda bukti penyertaan tersebut dikeluarkan surat saham/surat kolektif kepada pemegang saham.

2. Obligasi

Obligasi merupakan surat pernyataan utang dari perusahaan kepada para pembeli pinjaman, yakni para pemegang obligasi. Obligasi disebut juga surat utang yang berjangka panjang sekurang-kurangnya 3 tahun.

3. Reksadana

Reksadana merupakan sertifikat yang menjelaskan bahwa pemilik menitipkan uang kepada pengelola reksadana untuk digunakan sebagai modal berinvestasi di pasar uang atau pasar modal (Masruroh, 2015).

Sebagaimana layaknya suatu pasar yang mempunyai sifat pelaku yang antara lain terdiri dari penjual, pembeli, dan pemasok barang, pasar modal juga terdiri dari 
banyak pihak yang masing-masing memiliki peran sendiri. Para pihak atau yang lebih sering disebut sebagai pelaku pasar modal, meliputi:

1. Emiten

Emiten adalah pihak yang melakukan penawaran umum atau perusahaan yang memperoleh dana melalui pasar modal, sedangkan pemodal merupakan pembeli modal atau penanam modal dalam perusahaan.

2. Penjaminan emisi efek

Penjaminan emisi efek yaitu pihak yang membuat kontrak dengan emiten untuk melakukan penawaran umum bagi kepentingan emiten dengan atau tanpa kewajiban untuk membeli sisa efek yang tidak terjual.

3. Pelaku (Investor/Pemodal)

Pelaku, yakni pembeli dana/modal baik perorangan maupun kelembagaan/badan usaha yang menyisihkan kelebihan dana/uangnya untuk usaha yang bersifat produktif, serta adanya penjual modal/dana, yaitu perusahaan yang memerlukan dana atau tambahan modal untuk keperluan usahannya.

4. Komoditi

Komoditi adalah barang yang diperjualbelikan, dapat berupa bursa uang, modal, timah, karet, tembakau, minyak, emas, perkapalan, asuransi, perbankan, dan lain-lain.

5. Lembaga penunjang pasar modal

Lembaga penunjang pasar modal adalah yang terkait dalam kegiatan pasar modal serta lembaga-lembaga swasta yang terkait dalam sebagai profesi penunjang. Lembaga penunjang pasar modal, terdiri atas:

a. Bursa Efek yang menyelenggarakan dan menyediakan system atau sarana untuk mempertemukan penawaran jual dan beli efek pihak lain dengan tujuan memperdagangkan efek di antara mereka.

b. Biro Administrasi Efek, yaitu pihak yang berdasarkan kontrak dengan emiten melaksanakan pencatatan pemilikan emiten dan pembagian hak yang berkaitan dengan efek.

6. Profesi penunjang pasar modal

Profesi penunjang pasar modal di dalamnya meliputi akuntan publik, konsultan hokum, penilai, notaris, dan profesi lain yang ditetapkan dengan peraturan pemerintah (Nazir, 2016).

Pelaku utama yang menerbitkan sekuritas pasar modal ialah pemerintah dan perusahaan. Pemerintah biasanya menerbitkan promes jangka panjang dan obligasi untuk memperoleh dana pembangunan, misalnya jalan dan fasilitas umum. Oleh karena itu, dengan keberadaan pasar modal, maka perusahaan-perusahaan akan lebih mudah memperoleh dana, sehingga kegiatan ekonomi di berbagai sektor dapat ditingkatkan. Dengan dijualnya saham di pasar modal, berarti masyarakat diberikan kesempatan untuk memiliki dan menikmati keuntungan yang diperoleh perusahaan. Dengan kata lain, pasar modal dapat membantu pemerintah meningkatkan pendapatan dalam masyarakat. 
Sementara itu, dalam pasar modal ada dua kesempatan untuk menjadi pemodal, yakni:

1. Pasar perdana (primary market)

Pasar perdana (primary market) merupakan pemodal pada saat saham belum dilakukan atau efeknya belum tercatat di bursa, masanya adalah 90 hari.

2. Pasar sekunder (secondary market)

Pasar sekunder (secondary market) adalah setelah 90 hari pasar perdana maka dapat masuk ke pasar sekunder dan setelah itu efek dapat diperdagangkan setiap hari sesuai dengan mekanisme pasar.

\section{Saham}

Saham adalah bukti kepemilikan terhadap suatu perusahaan. Bukti kepemilikan ini terdapat dalam dua bentuk, yaitu saham yang dikeluarkan atas nama pemiliknya atau saham atas nama dan saham yang tidak mencantumkan nama pemiliknya atau saham atas unjuk. Saham atas nama (registered stock), merupakan saham yang ditulis dengan jelas siapa nama pemiloiknya, di mana cara peralihannya harus melalui prosedur tertentu. Sedangkan, saham atas unjuk (bearer stock), artinya pada saham tersebut tidak tertulis nama pemiliknya, agar mudah dipindahtangankan dari satu investor ke investor lainnya.

Harga saham mencerminkan keberhasilan pengelolaan perusahaan di mana keberhasilan ini akan menghasilkan keuntungan yang kemudian akan memberikan kepuasan bagi investor yang rasional. Harga saham yang cukup tinggi akan memberikan keuntungan, yaitu berupa capital gain dan citra yang lebih baik bagi perusahaan sehingga memudahkan bagi manajemen untuk mendapatkan dana dari luar perusahaan (Kennedy et al., 2010).

\section{Analisis Rasio}

Analisis rasio adalah analisis yang dilakukan dengan menghubungkan berbagai perkiraan yang ada di laporan keuangan dalam bentuk rasio keuangan. Analisis ini dapat mengungkapkan hubungan yang penting antar perkiraan laporan keuangan dan dapat digunakan untuk mengevaluasi kondisi keuangan dan kinerja perusahaan (Putri \& Sampurno, 2012).

Analisa rasio memiliki keunggulan dibanding teknik analisa lainnya. Keunggulan tersebut adalah:

1. Rasio merupakan angka-angka atau ikhtisar statistic yang lebih mudah dibaca dan ditafsirkan.

2. Merupakan pengganti yang lebih sederhana dari informasi yang disajikan laporan keuangan yang sangat rinci dan rumit.

3. Mengetahui posisi perusahaan di tengah industri lain.

4. Sangat bermanfaat untuk bahan dalam mengisi model-model pengambilan keputusan dan model prediksi (Z-score).

5. Menstandartisasi size perusahaan.

6. Lebih mudah memperbaningkan perusahaan dengan perusahaan lain atau melihat perkembangan perusahaan secara periodik atau "time series".

7. Lebih mudah melihat trend perusahaan serta melakukan prediksi di masa yang akan datang. 
Disamping keunggulan yang dimiliki analisa rasio ini, teknik ini juga memiliki beberapa keterbatasan yang harus didasari oleh penggunaannya agar tidak salah dalam penggunaannya. Adapun keterbatasan analisis rasio tersebut adalah:

1. Kesulitan dalam memilih rasio yang tepat yang dapat digunakan untuk kepentingan pemakainya.

2. Keterbatasan yang dimiliki akuntansi atau laporan keuangan juga menjadi keterbatasan teknik, seperti:

a. Bahan perhitungan rasio atau laporan keuangan itu banyak mengandung taksiran dan judgment yang dapat dinilai bias atau subyektif.

b. Nilai yang terkandung dalam laporan keuangan dan rasio adalah nilai perolehan (cost) bukan harga pasar.

c. Klasifikasi dalam laporan keuangan bisa berdampak pada angka rasio.

d. Metode pencatatan yang tergambar dalam standar akuntansi bisa diterapkan berbeda oleh perusahaan yang berbeda.

3. Jika data untuk menghitung rasio tidak tersedia maka akan menimbulkan kesulitan menghitung rasio.

4. Sulit jika data yang tersedia tidak sinkron.

5. Jika dua perusahaan dibandingkan bisa saja terknik dan standar akuntansi yang dipakai tidak sama. Oleh karenanya jika dilakukan perbandingan bisa menimbulkan kesalahan (Kasmir, 2014).

Jenis-jenis rasio keuangan yang dapat digunakan untuk menilai kinerja manajeman beragam. Penggunaan masing-masing rasio tergantung kebutuhan perusahaan, artinya terkadang semua rasio tidak digunakan. Dalam praktiknya terdapat beberpa macam jenis rasio untuk mengukur kinerja suatu perusahaan. Masing-masing jenis rasio yang digunakan akan memberikan arti tertentu tentang posisi yang diinginkan. Berikut jenis-jenis rasio keuangan:

1. Rasio Likuiditas

Fred Weston sebagaimana dikutip oleh Kasmir, menyebutkan bahwa rasio likuiditas (liquidity ratio) merupakan rasio yang menggambarkan kemampuan perusahaan memenuhi kewajiaban (utang) jangka pendek. Artinya apabila perusahaan ditagih, maka akan mampu untuk memenuhi hutang (membayar) tersebut terutama utang yang sudah jatuh tempo.

2. Rasio Solvabilitas (Leverage)

Rasio solvabilitas atau laverage ratio, merupakan rasio yang digunakan untuk mengukur sejauh mana aktiva perusahaan dibiayai dengan utang. Artinya, berapa besar beban utang yang ditanggung perusahaan dibandinkan dengan aktivanya. Dalam arti luas dikatakan bahwa rasio solvabilitas digunakan untuk mengukur kemampuan perusahaan untuk membayar seluruh kewajiban baik janka pendek maupun jangka panjang apabila perusahaan dibubarkan (dilikuidasi).

3. Rasio Aktivitas

Rasio aktivitas (activity ratio), merupakan rasio yang digunakan untuk mengukur efektivitas dalam menggunakan aktiva yang dimilikinya. Atau dapat dikatakan rasio ini digunakan untuk mengukur tingkat efesiensi pemanfaatan sumber daya perusahaan. Rasio aktivitas juga digunakan untuk menilai kemampuan perusahaan dalam melaksnakan aktivitas sehari-hari. 
4. Rasio Pertumbuhan

Rasio pertumbuhan (Growth Ratio), merupakan rasio yang menggambarkan kemampuan perusahaan mempertahankan posisi ekonominya di tengah pertumbuhan perekonomian dan sektor usahanya.

5. Rasio Penilaian

Rasio penilaian (Valuation Ratio), yaitu rasio yang memberikan ukuran kemampuan manajeman menciptakan nilai pasar usahanya di atas biaya investasi, seperti:

a. Rasio harga saham terhadap pendapatan.

b. Rasio nilai pasar saham terhadap nilai buku.

6. Rasio Profitabilitas

Rasio profitabilitas merupakan rasio untuk menilai kemampuan perusahaan dalam mencari keuntungan. Rasio ini juga memberikan ukuran tingkat efektivitas manajeman perusahaan. Hal ini ditunjukkan oleh laba yang dihasilkan dari penjualan dan pendapatan investasi (Nurcahyo, 2016). Penggunaan rasio profitabilitas dapat dilakukan dengan menggunakan perbandingan antara berbagai komponen yang ada di laporan keuangan, terutama laporan keuangan neraca dan periode operasi. Tujuannya adalah agar terlihat perkembangan perusahaan dalam rentang waktu tertentu, baik penurunan atau kenaikan sekaligus mencari penyebab penurunan tersebut. Hasil pengukuran tersebut dapat dijadikan alat evaluasi kinerja manajemen selama ini, apakah mereka telah bekerja secara efektif atau tidak.

Dalam praktiknya, jenis-jenis rasio profitabilitas yang dapat digunakan adalah:
a. Return on Equity
b. Return on Assets
c. Net Profit Margin
d. Earning Per Share

Penelitian ini menggunakan 3 (tiga) indikator dari rasio profitabilitas untuk mengukur kinerja perusahaan, yaitu:

1. Return on Assets (ROA/ROI)

Hasil pengembalian investasi atau dikenal dengan nama Return on Investment (ROI) atau Return on Total Assets (ROA) merupakan rasio yang menunjukkan hasil (return) atas jumlah aktiva yang digunakan dalam perusahaan. ROI juga merupakan suatu ukuran tentang efektivitas manajemen dalam mengelola investasinya.

Di samping itu, hasil pengembalian investasi menunjukkan produktivitas dari seluruh dana perusahaan, baik modal pinjaman maupun modal sendiri. Semakin kecil (rendah) rasio ini, maka semakin kurang baik, demikian pula sebaliknya. Artinya rasio ini digunakan untuk mengukur efektivitas dari keseluruhan operasi perusahaan.

$$
\text { Return On Assets }(R O A)=\frac{\text { Laba Bersih Setelah Pajak }}{\text { Total Asset }}
$$

Semakin tinggi Return on Asset suatu perusahaan, semakin besar pula tingkat keuntungan yang dicapai oleh perusahaan. Return on Asset perlu dipertimbangkan oleh investor dalam berinvestasi saham, karena Return on 
Asset berperan sebagai indikator efisiensi perusahaan dalam menggunakan aset untuk memperoleh laba.

2. Net Profit Margin (NPM)

Profit Margin on Sales atau Ratio Profit Margin atau margin laba atas penjualan salah satu rasio yang digunakan untuk mengukur margin laba atas penjualan. Cara pengukuran rasio ini adalah dengan membandingkan laba bersih setelah pajak dengan penjualan bersih. Rasio ini juga dikenal dengan nama Net Profit Margin.

Terdapat dua rumus untuk mencari profit margin, yaitu sebagai berikut (Kasmir, 2014):

a. Untuk margin laba kotor dengan rumus:

$$
\text { Profit Margin }=\frac{\text { Penjualan Bersih }- \text { Harga Pokok Penjualan }}{\text { Penjualan }}
$$

b. Untuk margin laba bersih dengan rumus:

$$
\text { Net Profit Margin }=\frac{\text { Earning After Interest and Tax }}{\text { Sales }}
$$

Semakin tinggi Net Profit Marginakan menunjukkan adanya efisiensi yang semakin tinggi, sehingga variabel ini menjadi faktor penting yang harus dipertimbangkan.

\section{Earning Per Share (EPS)}

EPS merupakan rasio yang menunjukkan berapa besar keuntungan (return) yang diperoleh investor atau pemegang saham. Semakin tinggi nilai EPS tentu saja menggembirakan pemegang saham karena semakin besar laba yang disediakan untuk pemegang saham.

Rasio Laba Per Lembar Saham (Earning Per Share) atau disebut juga rasio nilai buku, merupakan rasio untuk mengukur keberhasilan manajemen dalam mencapai keuntungan bagi pemegang saham. Rasio yang rendah berarti manajemen belum berhasil untuk memuaskan pemegang saham, sebaliknya dengan rasio yang tinggi. Maka kesejahteraan pemegang saham meningkat dengan pengertian lain, bahwa tingkat pengembalian yang tinggi (Kennedy dkk., 2010).

$$
\text { Laba Per Lembar Saham }(\text { EPS })=\frac{\text { Laba Saham }}{\text { Jumlah Saham Beredar }}
$$

Keuntungan bagi pemegang saham adalah jumlah keuntungan setelah dipotong pajak. Pada umumnya manajemen perusahaan, pemegang saham biasa dan calon pemegang saham tertarik akan Earning per Share, karena hal ini menggambarkan jumlah rupiah yang diperoleh untuk setiap lembar saham biasa. 


\section{Model Penelitian}

Dalam penelitian ini, peneliti akan melihat pengaruh masing-masing dan pengaruhnya secara simultan dari faktor-faktor seperti rasio ROA, NPM, dan EPS terhadap harga saham. Untuk memperjelas tentang arah dan tujuan dari penelitian secara utuh, maka perlu di uraikan suatu konsep berfikir dalam penelitian ini sehingga peneliti dapat menguraikan tentang gambaran rasio ROA, NPM, dan EPS terhadap harga saham.

\section{Gambar 1. Model Pengaruh Karakteristik Perusahaan Terhadap Harga Saham}

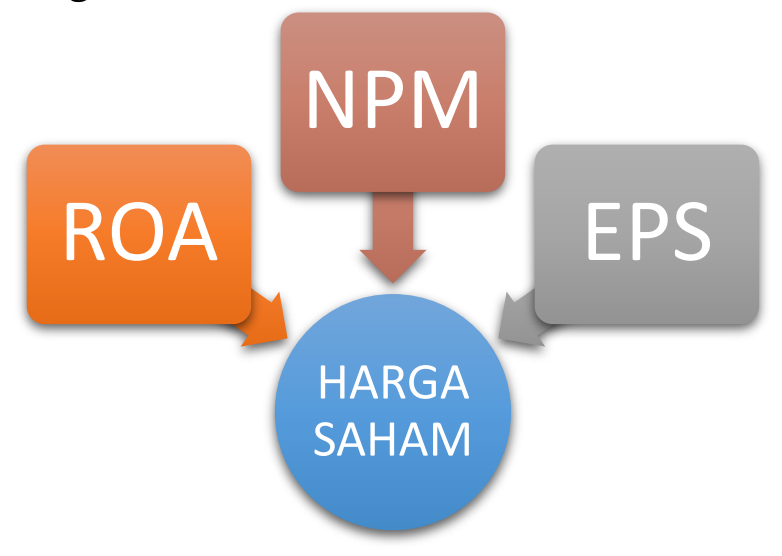

\section{METODE PENELITIAN}

Penelitian ini merupakan penelitian kausalitas/sebab akibat dengan pendekatan kuantitatif yang dibangun dengan teori yang sudah matang untuk mengetahui, meramalkan dan mengontrol suatu fenomena. Penelitian kuantitatif dipakai untuk menguji teori, menyajikan fakta atau mendeskripsikan statistik, menunjukan hubungan antar variabel, mengembangkan konsep, mengembangkan pemahaman, atau mendeskripsikan banyak hal. Koefisien korelasi dapat digunakan untuk menguji hipotesis tentang hubungan antar variabel atau untuk menyatakan besar-kecilnya hubungan antar variabel. Dalam penelitian ini yang akan diamati hubungan adalah ROA, NPM, EPS dan harga saham pada sub sektor industri rokok yang terdaftar dalam Bursa Efek Indonesia.

Populasi penelitian ini adalah seluruh perusahan rokok yang terdaftar di Bursa Efek Indonesia periode tahun 2015-2017. Dalam menentukan sampel digunakan teknik purposive sampling, yaitu tekhnik penentuan sampel dengan mempertimbangkan atau dengan kriteria-kriteria tertentu. Dengan kriteria sebagai berikut:

1. Perusahaan rokok yang terdaftar di BEI.

2. Menerbitkan laporan keuangan tahunan dalam kurun waktu 2015-2017.

3. Data disajikan per triwulan.

Jadi, berdasarkan kriteria di atas jumlah sampel yang digunakan dalam penelitian ini sebanyak 4 perusahaan yang secara rutin juga menerbitkan laporan keuangan per triwulan selama tiga tahun berturut-turut. Dari kriteria tersebut di peroleh sampel yaitu Gudang Garam Tbk. (GGRM), Handjaya Mandala Sampoerna Tbk. (HMSP), Bentoel International Investama Tbk. (RMBA), dan Wismilak Inti Makmur Tbk. (WIIM). 
Berikut adalah definisi operasinal digunakan peneliti dalam mengoperasionalkan variabel penelitian ini.

\section{Tabel 1. Tabel Definisi Operasional}

\begin{tabular}{|c|c|c|c|}
\hline Variabel & Definisi & Indikator & Skala \\
\hline \multirow{2}{*}{$\begin{array}{l}\text { Harga Saham } \\
(\mathrm{Y})\end{array}$} & \multirow[b]{2}{*}{$\begin{array}{l}\text { Harga saham adalah } \\
\text { sebesar nilai sekarang } \\
\text { atau present value dari } \\
\text { aliran kas yang } \\
\text { diharapkan akan } \\
\text { diterima. }\end{array}$} & net income - deviden & \multirow[b]{2}{*}{ Rasio } \\
\hline & & $\overline{\text { jumlah saham beredar }}$ & \\
\hline \multirow{8}{*}{$\begin{array}{l}\text { Return On } \\
\text { Assets (X1) }\end{array}$} & \multirow{8}{*}{$\begin{array}{l}\text { Return On Asset adalah } \\
\text { sama dengan Return On } \\
\text { Investment dalam } \\
\text { analisa keuangan } \\
\text { mempunyai arti sangat } \\
\text { penting sebagai salah } \\
\text { satu teknik analisa } \\
\text { keuangan yang bersifat } \\
\text { menyeluruh } \\
\text { (komprehensif). }\end{array}$} & & \multirow[t]{8}{*}{ Rasio } \\
\hline & & laba bersih setelah pajak & \\
\hline & & $\overline{\text { total aset }}$ & \\
\hline & & & \\
\hline & & & \\
\hline & & & \\
\hline & & & \\
\hline & & & \\
\hline \multirow{2}{*}{$\begin{array}{l}\text { Net Profit } \\
\text { Margin }(X 2)\end{array}$} & \multirow{2}{*}{$\begin{array}{l}\text { Net Profit Margin } \\
\text { merupakan rasio yang } \\
\text { digunakan untuk } \\
\text { mengukur laba atas } \\
\text { penjualan. }\end{array}$} & laba bersih setelah pajak & \multirow[t]{2}{*}{ Rasio } \\
\hline & & penjualan bersih & \\
\hline \multirow{2}{*}{$\begin{array}{l}\text { Earning Per } \\
\text { Share (X3) }\end{array}$} & Earning per Share adalah & laba saham & \multirow[t]{2}{*}{ Rasio } \\
\hline & $\begin{array}{l}\text { rasio untuk mengukur } \\
\text { keberhasilan } \\
\text { manajemen dalam } \\
\text { mencapai keuntungan } \\
\text { bagi pemegang saham. }\end{array}$ & $\overline{\text { jumlah saham beredar }}$ & \\
\hline
\end{tabular}

Data penelitian berupa laporan keuangan perusahaan rokok yang terdaftar di Bursa Efek Indonesia dalam periode tahun 2015-2017. Data tersebut diperoleh melalui di website resmi Bursa Efek Indonesia (www.idx.co.id). Selanjutnya data dianalisis menggunakan analisis regresi linear berganda dengan model persamaan regresi sebagai berikut:

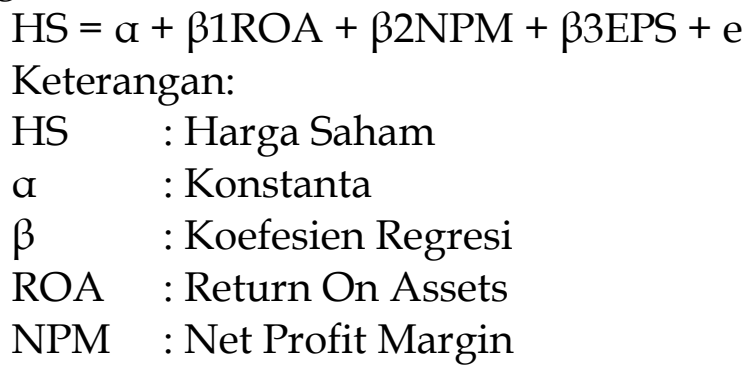




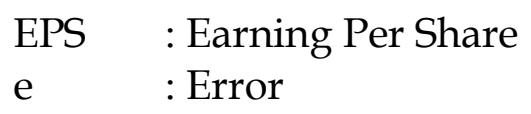

\section{HASIL DAN PEMBAHASAN}

\section{Profil Ringkas Responden}

1. PT. Gudang Garam Tbk.

PT Gudang Garam Tbk mampu mencatat pertumbuhan kinerja solid pada 2015. Manajemen perseroan berhasil mengatasi kenaikan beban operasional sehingga laba tetap tumbuh. Selain itu, kinerja keuangan GGRM yang solid juga didukung oleh meningkatnya permintaan terhadap produk rokok perseroan. GGRM memiliki konsumen loyal sehingga perlambatan ekonomi domestik tidak menghalangi pertumbuhan penjualan perseroan. Kinerja keuangan perseroan yang tumbuh ikut berdampak positif terhadap harga saham GGRM di bursa. Menurut data Bursa Efek Indonesia (BEI), harga saham GGRM untuk periode 30 Desember 2015 - 30 Desember 2016 naik Rp 8.900 (16,18\%) dari harga penutupan sebesar Rp 55.000 menjadi Rp 63.900 per unit. Harga saham GGRM terus mengalami kenaikan untuk periode 30 Desember 2016 - 29 Desember 2107 dari harga penutupan sebesar Rp 63.900 menjadi Rp 83.800, naik Rp 19.000 (31,14\%).

2. $\quad$ PT Hanjaya Mandala Sampoerna Tbk. (HMSP)

Kegiatan usaha Sampoerna memberikan lapangan kerja secara keseluruhan bagi 89,500 orang. Angka tersebut meliputi sekitar 61,000 orang yang merupakan pekerja dari 38 unit Mitra Produksi Sigaret yang berlokasi di 27 kabupaten di Pulau Jawa. Menurut data Bursa Efek Indonesia (BEI), harga saham HMSP untuk periode 30 Desember 2015 - 30 Desember 2016 mengalami kenaikan Rp70 (1,86\%) dari harga penutupan sebesar Rp 3.760 menjadi Rp 3.830 per unit. Harga saham HMSP juga mengalami kenaikan untuk periode 30 Desember 2016 - 29 Desember 2107 dari harga penutupan sebesar Rp 3.830 menjadi Rp 4.730, naik Rp 900 (23,50\%). PT Hanjaya Mandala Sampoerna mampu mempertahankan kinerja yang meningkat meski tipis. Salah satu faktornya adalah potensi kenaikan cukai rokok yang berimbas pada harga jual rokok, sehingga harga saham HMSP masih fluktuatif.

3. PT Bentoel Internasional Investama Tbk. (RMBA)

Menurut data Bursa Efek Indonesia (BEI), harga saham RMBA untuk periode 23 Desember 2015 - 21 Desember 2016 turun Rp26 (5,10\%) dari harga penutupan sebesar Rp 510 menjadi Rp484 per unit. Harga saham RMBA terus mengalami penurunan untuk periode 21 Desember 2016 - 29 Desember 2107 dari harga penutupan sebesar Rp 484 menjadi Rp 380, turun Rp 104 (21,49\%). Faktor penurunan ini dikarenakan kenaikan beban pokok penjualan, peningkatan tarif cukai, peningkatan harga tembakau dan bahan baku lain, depresiasi yang lebih tinggi, serta pelunasan pinjaman antar perusahaan. Akibatnya, perusahaan RMBA melaporkan kerugian usaha sebesar Rp 2,1 triliun. 


\section{PT Wismilak Inti Makmur Tbk}

Pada 18 Desember 2012, perusahaan ini resmi melantai di Bursa Efek Indonesia dengan kode WIIM. Sebenarnya, pencatatan saham perdana perusahaan ini sudah direncanakan sejak 1995, namun karena krisis keuangan 1997-1998 itulah yang membuat perusahaan ini mengurungkan rencana tersebut. Saat ini Wismilak memiliki 20 kantor cabang, 4 stock points dan 29 agen terbear di seluruh pilau terbesar Indonesia. Menurut data Bursa Efek Indonesia (BEI), harga saham WIIM untuk periode 30 Desember 2015 - 30 Desember 2016 naik Rp 10 (2,33\%) dari harga penutupan sebesar Rp 430 menjadi Rp 440 per unit. Harga saham WIIM mengalami penurunan untuk periode 30 Desember 2016 - 29 Desember 2017 dari harga penutupan sebesar Rp 440 menjadi Rp 290, turun Rp 150 (34,09\%). Kinerja PT Wismilak Inti Makmur mencatatkan penurunan. Penurunan kinerja ini semakin tertekan karena beban usaha yang meningkat dan tingginya tarif cukai rokok.

\section{Deskripsi Data Penelitian} Return On Assets (ROA)

Return on Total Assets (ROA) merupakan rasio yang menunjukkan hasil (return) atas jumlah aktiva yang digunakan dalam perusahaan. Artinya rasio ini digunakan untuk mengukur efektivitas dari keseluruhan operasi perusahaan. Berikut merupakan data return on assets perusahaan subsektor industri pangan rokok yang terdaftar di Bursa Efek Indonesia yang menjadi sampel penelitian selama periode 2015-2017:

\section{Tabel 2. Hasil Perhitungan Return On Assets (ROA)}

\begin{tabular}{|c|c|c|c|c|c|c|}
\hline \multirow[t]{2}{*}{ Tahun } & \multirow[t]{2}{*}{ No } & \multirow[t]{2}{*}{ Nama Perusahaan } & \multicolumn{4}{|c|}{ Triwulan } \\
\hline & & & 1 & 2 & 3 & 4 \\
\hline \multirow[t]{4}{*}{2015} & 1 & Gudang Garam Tbk & 2,15 & 4,04 & 6,92 & 10,13 \\
\hline & 2 & $\begin{array}{l}\text { Hanjaya Mandala } \\
\text { Sampoerna Tbk }\end{array}$ & 9,82 & 17,59 & 24,06 & 27,26 \\
\hline & 3 & $\begin{array}{l}\text { Bentoel International } \\
\text { Investama Tbk }\end{array}$ & $-3,51$ & $-7,14$ & $-10,86$ & $-12,94$ \\
\hline & 4 & Wismilak Inti Makmur Tbk & 2,65 & 4,72 & 6,97 & 9,75 \\
\hline \multirow[t]{4}{*}{2016} & 1 & Gudang Garam Tbk & 2,68 & 4,52 & 7,33 & 10,6 \\
\hline & 2 & $\begin{array}{l}\text { Hanjaya Mandala } \\
\text { Sampoerna Tbk }\end{array}$ & 6,54 & 15,63 & 21,43 & 30,02 \\
\hline & 3 & $\begin{array}{l}\text { Bentoel International } \\
\text { Investama Tbk }\end{array}$ & $-2,83$ & $-4,69$ & $-11,52$ & $-15,48$ \\
\hline & 4 & Wismilak Inti Makmur Tbk & 2,7 & 4,45 & 6,15 & 7,84 \\
\hline \multirow[t]{4}{*}{2017} & 1 & Gudang Garam Tbk & 3,18 & 5,01 & 8,63 & 11,61 \\
\hline & 2 & $\begin{array}{l}\text { Hanjaya Mandala } \\
\text { Sampoerna Tbk }\end{array}$ & 6,35 & 14,66 & 20,06 & 29,37 \\
\hline & 3 & $\begin{array}{l}\text { Bentoel International } \\
\text { Investama Tbk }\end{array}$ & $-0,48$ & $-3,9$ & $-5,86$ & $-3,41$ \\
\hline & 4 & Wismilak Inti Makmur Tbk & 1,43 & 0,89 & 2,13 & 3,31 \\
\hline
\end{tabular}


Sumber: data sekunder yang diolah

\section{Net Profit Margin (NPM)}

Berikut merupakan data Net Profit Margin perusahaan subsektor industri pangan rokok yang terdaftar di Bursa Efek Indonesia yang menjadi sampel penelitian selama periode 2015-2017:

\section{Tabel 3. Hasil Perhitungan Net Profit Margin (NPM)}

\begin{tabular}{|c|c|c|c|c|c|c|}
\hline \multirow[t]{2}{*}{ Tahun } & \multirow[t]{2}{*}{ No } & \multirow[t]{2}{*}{ Nama Perusahaan } & \multicolumn{4}{|c|}{ Triwulan } \\
\hline & & & 1 & 2 & 3 & 4 \\
\hline \multirow[t]{4}{*}{2015} & 1 & Gudang Garam Tbk & 1,282 & 2,402 & 4,1 & 6,436 \\
\hline & 2 & $\begin{array}{l}\text { Hanjaya Mandala Sampoerna } \\
\text { Tbk }\end{array}$ & 2,899 & 5,01 & 7,597 & 10,363 \\
\hline & 3 & $\begin{array}{l}\text { Bentoel International } \\
\text { Investama Tbk }\end{array}$ & -383 & -775 & $-1,169$ & $-1,639$ \\
\hline & 4 & Wismilak Inti Makmur Tbk & 33 & 58 & 91 & 131 \\
\hline \multirow[t]{4}{*}{2016} & 1 & Gudang Garam Tbk & 1,693 & 2,869 & 4,601 & 6,67 \\
\hline & 2 & $\begin{array}{l}\text { Hanjaya Mandala Sampoerna } \\
\text { Tbk }\end{array}$ & 3,119 & 6,14 & 9,081 & 12,762 \\
\hline & 3 & $\begin{array}{l}\text { Bentoel International } \\
\text { Investama Tbk }\end{array}$ & -331 & -676 & $-1,645$ & $-2,086$ \\
\hline & 4 & Wismilak Inti Makmur Tbk & 35 & 61 & 79 & 106 \\
\hline \multirow[t]{4}{*}{2017} & 1 & Gudang Garam Tbk & 1,89 & 3,125 & 5,41 & 7,754 \\
\hline & 2 & $\begin{array}{l}\text { Hanjaya Mandala Sampoerna } \\
\text { Tbk }\end{array}$ & 3,291 & 6,05 & 9,338 & 12,671 \\
\hline & 3 & $\begin{array}{l}\text { Bentoel International } \\
\text { Investama Tbk }\end{array}$ & -69 & -549 & -811 & -480 \\
\hline & 4 & Wismilak Inti Makmur Tbk & 19 & 12 & 27 & 41 \\
\hline
\end{tabular}

Sumber: data sekunder yang diolah

\section{Earning Per Share (EPS)}

Berikut merupakan data Earning Per Share perusahaan subsektor industri pangan rokok yang terdaftar di Bursa Efek Indonesia yang menjadi sampel penelitian selama periode 2015-2017:

Tabel 4. Hasil Perhitungan Earning Per Share (EPS)

\begin{tabular}{|c|c|c|c|c|c|c|}
\hline \multirow[t]{2}{*}{ Tahun } & \multirow[t]{2}{*}{ No } & \multirow[t]{2}{*}{ Nama Perusahaan } & \multicolumn{4}{|c|}{ Triwulan } \\
\hline & & & 1 & 2 & 3 & 4 \\
\hline \multirow[t]{4}{*}{2015} & 1 & Gudang Garam Tbk & 674,72 & 1264,4 & 2161,6 & 3387,2 \\
\hline & 2 & $\begin{array}{l}\text { Hanjaya Mandala Sampoerna } \\
\text { Tbk }\end{array}$ & 658,95 & 1139 & 1726,5 & 2205 \\
\hline & 3 & $\begin{array}{l}\text { Bentoel International } \\
\text { Investama Tbk }\end{array}$ & $-53,41$ & $-104,93$ & $-162,3$ & $-227,57$ \\
\hline & 4 & Wismilak Inti Makmur Tbk & 15,92 & 27,42 & 43,48 & 62,34 \\
\hline
\end{tabular}




\begin{tabular}{rrlrrrr}
2016 & 1 & Gudang Garam Tbk & 891,25 & 1510,1 & 2421,8 & 3510,6 \\
\cline { 2 - 6 } & 2 & Hanjaya Mandala Sampoerna & 663,56 & 52,86 & 78,09 & 109,74 \\
& Tbk & & & & \\
\cline { 2 - 6 } & 3 & $\begin{array}{l}\text { Bentoel International } \\
\text { Investama Tbk }\end{array}$ & $-45,95$ & $-18,57$ & $-45,18$ & $-57,3$ \\
\cline { 2 - 6 } & 4 & Wismilak Inti Makmur Tbk & 16,74 & 28,9 & 37,64 & 50,55 \\
\hline 2017 & 1 & Gudang Garam Tbk & 994,56 & 1644,5 & 2851,6 & 4080,9 \\
\cline { 2 - 6 } & 2 & $\begin{array}{l}\text { Hanjaya Mandala Sampoerna } \\
\text { Tbk }\end{array}$ & 28,3 & 52,02 & 80,29 & 108,95 \\
& 3 & $-1,9$ & $-15,09$ & $-22,27$ & $-13,19$ \\
& Bentoel International & & & & \\
\hline & Investama Tbk & Wismilak Inti Makmur Tbk & 9,07 & 5,51 & 12,65 & 19,3 \\
\hline
\end{tabular}

Sumber: data sekunder yang diolah

\section{Harga Saham (HS)}

Berikut merupakan data harga saham perusahaan subsektor industri pangan rokok yang terdaftar di Bursa Efek Indonesia yang menjadi sampel penelitian selama periode 2015-2017:

\section{Tabel 5. Hasil Perhitungan Harga Saham}

\begin{tabular}{|c|c|c|c|c|c|c|}
\hline \multirow[t]{2}{*}{ Tahun } & \multirow[t]{2}{*}{ No } & \multirow[t]{2}{*}{ Nama Perusahaan } & \multicolumn{4}{|c|}{ Triwulan } \\
\hline & & & 1 & 2 & 3 & 4 \\
\hline \multirow[t]{4}{*}{2015} & 1 & Gudang Garam Tbk & 51000 & 45100 & 42000 & 55000 \\
\hline & 2 & $\begin{array}{l}\text { Hanjaya Mandala Sampoerna } \\
\text { Tbk }\end{array}$ & 73475 & 72000 & 75975 & 94000 \\
\hline & 3 & $\begin{array}{l}\text { Bentoel International } \\
\text { Investama Tbk }\end{array}$ & 580 & 550 & 480 & 510 \\
\hline & 4 & Wismilak Inti Makmur Tbk & 540 & 410 & 378 & 430 \\
\hline \multirow[t]{4}{*}{2016} & 1 & Gudang Garam Tbk & 65000 & 69000 & 62000 & 63900 \\
\hline & 2 & $\begin{array}{l}\text { Hanjaya Mandala Sampoerna } \\
\text { Tbk }\end{array}$ & 94400 & 3800 & 3950 & 3830 \\
\hline & 3 & $\begin{array}{l}\text { Bentoel International } \\
\text { Investama Tbk }\end{array}$ & 475 & 442 & 468 & 484 \\
\hline & 4 & Wismilak Inti Makmur Tbk & 399 & 390 & 410 & 440 \\
\hline \multirow[t]{4}{*}{2017} & 1 & Gudang Garam Tbk & 65525 & 78300 & 65800 & 83800 \\
\hline & 2 & $\begin{array}{l}\text { Hanjaya Mandala Sampoerna } \\
\text { Tbk }\end{array}$ & 3900 & 3840 & 3860 & 4730 \\
\hline & 3 & $\begin{array}{l}\text { Bentoel International } \\
\text { Investama Tbk }\end{array}$ & 430 & 468 & 398 & 380 \\
\hline & 4 & Wismilak Inti Makmur Tbk & 452 & 428 & 318 & 290 \\
\hline
\end{tabular}

Sumber: data sekunder yang diolah 


\section{Hasil Uji Hipotesis}

Analisis ini dilakukan untuk menguji hipotesis dari penelitian yang telah dirumuskan sebelumnya, yaitu untuk mengetahui apakah ada pengaruh antara ROA, NPM, dan EPS terhadap Harga Saham. Hubungan antara variable independen dengan variable dependen dalam penelitian ini dituliskan dalam persamaan regresi linear berganda sebagai berikut:

\section{Tabel 6. Tabel Uji Hipotesis}

\begin{tabular}{|c|c|c|c|}
\hline No. & Uji Hipotesis & Hasil & Keterangan \\
\hline 1 & $\begin{array}{c}\text { Uji } \\
\text { Koefesien } \\
\text { Determinasi } \\
\text { (R2) }\end{array}$ & $\begin{array}{lr}\text { Berdasarkan } & \text { hasil } \\
\text { Koefesien } & \text { Determinasi } \\
\text { (Adjusted } R \quad \text { Square) } \\
\text { memiliki angka } 0,611 .\end{array}$ & 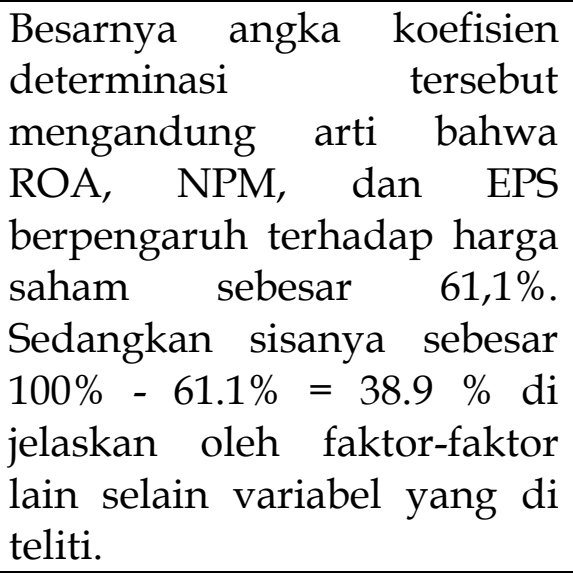 \\
\hline 2 & Uji Statistik t & $\begin{array}{l}\text { Dari hasil pengujian uji } \\
\text { signifikasi parameter } \\
\text { individual diketahui: } \\
\text { Nilai thitung } \\
\text { ROA }(X 1)=0,794 \text {, Sig. }= \\
0,431 \\
\text { NPM }(X 2)=7,790 \text {, Sig. }= \\
0,000 \\
\text { EPS }(X 3)=0,044, \text { Sig. }= \\
0,662\end{array}$ & $\begin{array}{l}\text { Dari data disamping dapat } \\
\text { disimpulkan bahwa: } \\
\text { (X1): ROA tidak berpengaruh } \\
\text { signifikan terhadap harga } \\
\text { saham. } \\
\text { (X2): NPM berpengaruh } \\
\text { signifikan terhadap harga } \\
\text { saham. } \\
\text { (X3): EPS tidak berpengaruh } \\
\text { signifikan terhadap harga } \\
\text { saham. }\end{array}$ \\
\hline 3 & Uji Statistik f & 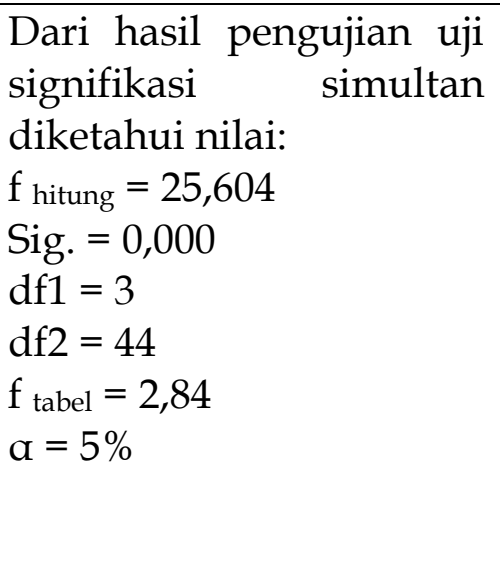 & $\begin{array}{l}\text { Nilai F hitung }>\text { F tabel atau } \\
25,604>2,84 \text { dan nilai Sig } \\
0,000 \text { maka dapat di } \\
\text { simpulkan bahwa ada } \\
\text { pengaruh yang signifikan } \\
\text { secara simultan antara } \\
\text { variabel bebas }(X) \text { yaitu ROA, } \\
\text { NPM dan EPS variabel terikat } \\
\text { yaitu harga saham (Y) pada } \\
\text { perusahaan sektor industi } \\
\text { rokok periode } 2015-2017 \text {. }\end{array}$ \\
\hline
\end{tabular}

Sumber : Data sekunder yang diolah, 2018 


\section{Pembahasan}

\section{Pengaruh ROA Terhadap Harga Saham Pada Perusahaan Rokok Yang Terdaftar di BEI Tahun 2015-2017}

Berdasarkan hasil penelitian didapatkan bahwa ROA tidak berpengaruh signifikan terhadap harga saham pada perusahaan rokok yang terdaftar di BEI periode 2015-2017. Jika berpengaruh siginifikan, maka kriteria pengujiannya yaitu apabila nilai ROA uji $\mathrm{t}<$ taraf signifikannya $5 \%(a=0,05)$. Hasil perhitungan menggunakan SPSS versi 23 dapat diketahui bahwa variabel ROA memiliki nilai $t$ hitung sebesar 0,794. Ini menunjukkan bahwa t hitung $<\mathrm{t}$ tabel yaitu 0,794<2,014. Dan di lihat dari tingkat signifikansi dalam table ROA memiliki tingkat signifikansi sebesar 0,431 yang berarti 0,431>0,05. Jadi dapat di simpulkan bahwa ROA tidak berpengaruh terhadap naik turunnya harga saham.

Hal ini sejalan dengan penelitian yang di lakukan oleh (Vireyto dan Sulasmiyati, 2017) yang menunjukkan bahwa variable ROA tidak berpengaruh terhadap harga saham pada perusahaan sektor perbankan di BEI. ROA memiliki pengaruh rendah terhadap harga saham. Hal tersebut kemungkinan terjadi karena perusahaan sektor industri rokok memiliki data komponen ROA yaitu laba sebelum pajak dan total asset yang tidak stabil pada setiap tahun selama periode 2015-2017. Faktornya adalah investor tidak hanya memperhatikan kemampuan internal perusahaan dalam menghasilkan keuntungan investasinya tetapi memperhatikan risiko eksternal serta kondisi pasar. Risiko eksternal dapat berupa inflasi, kenaikan tarif, perubahan kebijakan ekonomi, kenaikan beban pokok penjualan, depresiasi yang lebih tinggi, serta politik. Permintaan dan penawaran di pasar modal juga berpengaruh dalam kepuasan investasi yang dapat mengakibatkan fluktuasi harga saham. Jadi besar kecilnya ROA tidak serta merta mempengaruhi tinggi rendahnya harga saham, artinya perusahaan kurang maksimal dalam pengelolaan asset untuk menghasilkan laba.

\section{Pengaruh NPM Terhadap Harga Saham Pada Perusahaan Rokok Yang Terdaftar di BEI Tahun 2015-2017}

Berdasarkan hasil penelitian didapatkan bahwa NPM berpengaruh signifikan terhadap struktur modal pada perusahaan rokok yang terdaftar di BEI periode 20152017. Dimana kriteria pengujiannya yaitu apabila nilai probabilitas uji $\mathrm{t}<$ taraf signifikannya 5\% $(\alpha=0.05)$. Hasil perhitungan menggunakan SPSS versi 23 dapat di ketahui bahwa variabel NPM memiliki nilai thitung sebesar 7,790. Ini menunjukkan bahwa thitung $>\mathrm{t}$ tabel yaitu 7,790 $>2,014$. Dan dilihat dari tingkat signifikansi dalam tabel NPM memiliki tingkat signifikansi sebesar 0,000 yang berarti 0,00<0,05. Jadi dapat di simpulkan bahwa NPM berpengaruh positif dan signifikan terhadap harga saham secara parsial.

Hal ini sejalan dengan penelitian yang di lakukan (Watung dan Ilat, 2015) yang menunjukkan NPM berpengaruh signifikan terhadap harga saham pada perusahaan perbankan yang terdaftar di BEI. Hal tersebut menunjukkan bahwa perusahaan sektor industri rokok menunjukan kinerja perusahaan yang produktif untuk memperoleh laba yang tinggi melalui tingkat penjualan tertentu serta kemampuan perusahaan yang baik dalam menekan biaya-biaya oprasionalnya sehingga mampu 
menghasilkan keuntungan bersih. Sehingga meningkatkan kepercayaan investor untuk menginvestasikan modalnya pada perusahaan tersebut sehingga permintaan akan saham perusahaan meningkat yang otomatis akan diikuti peningkatan harga saham tersebut.Hal ini terlihat dari rata-rata NPM yang tiap tahunnya meningkat diimbangi dengan kenaikan harga saham. Karena NPM memiliki pengaruh yang paling tinggi terhadap harga saham sehingga kemampuan perusahaan untuk mendapat laba juga tinggi. Semakin tinggi tingkat penjualan maka semakin produktif perusahaan tersebut.

\section{Pengaruh EPS Terhadap Harga Saham Pada Perusahaan Rokok Yang Terdaftar di BEI Tahun 2015-2017}

Berdasarkan hasil penelitian didapatkan bahwa EPS tidak berpengaruh signifikan terhadap struktur modal pada perusahaan rokok yang terdaftar di BEI periode 2015-2017. Jika berpengaruh siginifikan, maka kriteria pengujiannya yaitu apabila nilai ROA uji $\mathrm{t}<$ taraf signifikannya $5 \%(\alpha=0,05)$. Hasil perhitungan menggunakan SPSS versi 23 dapat di ketahui bahwa variable EPS memiliki nilai thitung sebesar 0,440. Ini menunjukkan bahwa thitung $<\mathrm{t}$ tabel yaitu 0,440<2,014. Dan di lihat dari tingkat signifikansi dalam tabel EPS memiliki tingkat signifikansi sebesar 0,662 yang berarti 0,662 >0,05. Jadi dapat di simpulkan bahwa EPS tidak berpengaruh terhadap harga saham.

Hal ini sejalan dengan penelitian yang di lakukan (Hanum, 2015) yang menunjukkan EPS tidak berpengaruh terhadap harga saham pada perusahaan sun sektor batu bara yang terdaftar di BEI. Hal tersebut terjadi karena EPS pada perusahaan industri rokok tidak stabil pada setiap tahun selama periode 2015-2017. Dalam memperdagangkan saham, laba per saham dapat mempengaruhi harga saham, karena para investor selalu memperhatikan akan pertumbuhan laba per saham. Faktornya adalah investor tidak hanya memperhatikan kemampuan internal perusahaan dalam menghasilkan keuntungan investasinya tetapi memperhatikan risiko eksternal. Seperti kenaikan beban pokok penjualan, depresiasi yang lebih tinggi, hutang, peningkatan harga tembakau dan bahan baku lain, serta kondisi perekonomian secara makro yaitu kurs. Apabila sebagian besar bahan baku perusahaan menggunakan bahan baku impor, secara otomatis akan mengakibatkan kenaikan biaya produksi yang tentunya akan mengurangi tingkat keuntungan perusahaan. Penurunan tingkat keuntungan pada perusahaan secara langsung akan menurunkan laba per lembar saham. Sehingga investor akan mempertimbangkan untuk menginvestasikan modalnya di perusahaan tersebut.

\section{SIMPULAN}

Industri rokok di Indonesia adalah salah satu sektor domestik yang cukup strategis dengan tingkat daya saing tinggi dan berkontribusi signifikan terhadap perekonomian nasional. Kontribusi ini ditinjau dari sisi tembakau dan produkproduk turunannya yang memberikan manfaat seperti penerimaan negara (dari bea dan cukai), penyerapan tenaga kerja, komoditas unggulan petani, beasiswa pendidikan, dan sponsor berbagai kegiatan olahraga. Tingkat profitabilitas yang tinggi pada industri ini pada akhirnya memberikan dampak yang signikan terhadap perekonomian negara. Harga saham mencerminkan keberhasilan pengelolaan 
perusahaan di mana keberhasilan ini akan menghasilkan keuntungan yang kemudian akan memberikan kepuasan bagi stakeholder. Hasil penelitian menunjukkan bahwa ROA dan EPS tidak memiliki pengaruh signifikan terhadap harga saham. Hanya NPM yang berpengaruh signifikan terhadap harga saham. Dengan demikian, semakin tinggi Net Profit Margin akan menunjukkan adanya efisiensi yang semakin tinggi, sehingga variabel ini menjadi faktor penting yang harus dipertimbangkan bagi perusahaan.

\section{DAFTAR PUSTAKA}

Astuti, K. D., Retnowati, W., dan Rosyid, A. (2015). Pengaruh Struktur Modal Terhadap Profitabilitas (Studi Pada Perusahaan Go Publik Yang Menjadi 100 Perusahaan Terbaik Versi Majalah Fortune Indonesia Periode Tahun 2010-2012). Jurnal Akuntansi, 2(2339-2436), 49-60.

Hanum, Z. (2015). Pengaruh Return On Asset (ROE), Return On Equity (ROE), dan Earning Per Share (EPS) Terhadap Harga Saham pada Perusahaan Otomotif yang Terdaftar Di Bursa Efek Indonesia Periode 2008-2011. Jurnal Manajemen Dan Bisnis, 08, 1-9. Retrieved from jurnal.umsu.ac.id

Kasmir. (2014). Laporan Keuangan Bank. In Manajemen Perbankan.

Kennedy, S. M., Zheng, C. X., Tang, W. X., Paganin, D. M., dan Jesson, D. E. (2010). Laplacian image contrast in mirror electron microscopy. In Proceedings of the Royal Society A: Mathematical, Physical and Engineering Sciences (Vol. 466, pp. 2857-2874). https:/ / doi.org/10.1098/rspa.2010.0093

Kiyat, W. El. (2012). Peran Industri Rokok dalam Mengatasi Krisis Ekonomi, Mungkinkah Menjawab Polemik Keberadaan Rokok di Indonesia. In The Book of 2nd IPHSS: Di Balik Kisruh Regulasi Rokok, Sebuah Tinjauan Komprehensif dari Pemuda untuk Bangsa.

Masruroh, A. (2015). KONSEP DASAR INVESTASI REKSADANA. SALAM: Jurnal Sosial Dan Budaya Syar'i. https:/ / doi.org/10.15408/sjsbs.v1i1.1526

Nazir, A. (2016). Pasar Modal Syariah di Indonesia. HIKAMUNA.

Nurcahyo, G. A. (2016). Analisis pengaruh rasio keuangan terhadap harga saham pada perusahaan manufaktur yang terdaftar di bursa efek indonesia. Ilmiah Manejemen Bisnis.

Putri, A. A. B., dan Sampurno, R. D. (2012). Analisis pengaruh ROA, EPS, NPM, DER dan PBV terhadap return saham (Studi kasus pada industri Real Estate and Property yang terdaftar di Bursa Efek Indonesia periode 2007-2009). Diponegoro Business Review.

Vireyto, N., dan Sulasmiyati, S. (2017). Analisis Pengaruh Return On Asset, Return On Equity, dan Earning Per Share Terhadap Harga. Jurnal Administrasi Bisnis, 51(2).

Watung, R. W., dan Ilat, V. (2015). Pengaruh Return On Assets (ROA), Net Profit Margin (NPM), Dan Earning Per Share (EPS) Terhadap Harga Saham Pada Perusahaan Perbankan Di Bursa Efek Indonesia Periode 2011-2015. Jurnal Akuntansi Biaya \& Keuangan, 4(2), 518-529. https://doi.org/10.1007/s10834-0119265-0.

Wibowo, E. A. (2013). Studi Tentang Hubungna ROA, ROE, dan EPS Terhadap Harga Saham Perusahaan Perbankan Yang Terdaftar di BEI Tahun 2011-2013. Eprints.Dinus.Ac.Id. 